\title{
Awards leave Amy and Carly
}
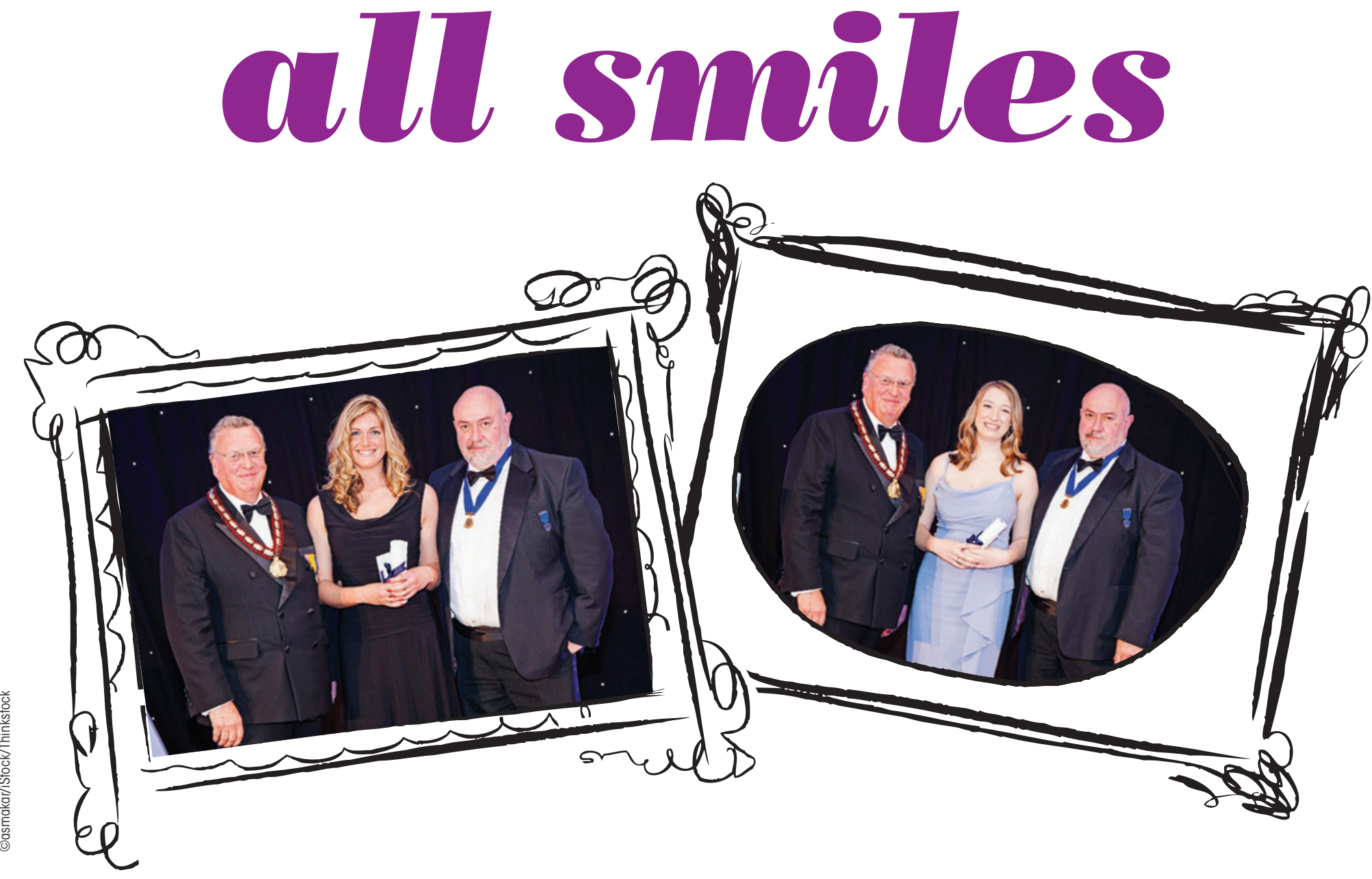

BDA Education have

awarded two DCPs the Outstanding Student of 2014 Award.

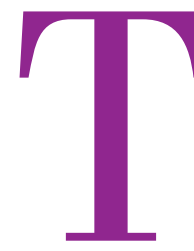

he accolade was awarded to the two students that achieved the highest standing in their BDA Radiography and Oral Health Education examinations held in 2014.

The awards were presented by Mick Armstrong, Chair of the BDA Principal Executive Committee, and Professor Nairn Wilson, BDA President, at the British Dental Conference and Exhibition 2015 held in Manchester in May. This is the second year that the Award has been given for Radiography, but the first time for Oral Health Education.

\section{'I FELT VERY PROUD TO BE HONOURED WITH MY}

\section{AWARD, AND IT WAS LOVELY TO MEET A DIVERSITY}

\section{OF PEOPLE FROM THE DENTAL SECTOR'}

Amy and Carly shared with us their feelings on receiving their awards, and their experiences of completing their online qualifications.

Amy Hambly-Symons, BDA Education Outstanding Radiography Student of 2014.

Amy attained the highest examination result for her performance in the March 2014 Radiography exam. She qualified as a Dental Nurse in 2011, winning the "Gold Award" that year for achieving the highest mark in the UK. Amy has been working at River Practice Specialist Centre in Truro, Cornwall since 2013.

How did it feel to win your prize?

The Midland Hotel was the perfect host for a fantastic evening. I felt very proud to be honoured with my award, and it was lovely to meet a diversity of people from the dental sector. I very much enjoyed the jazz band too!

What did you think of the online Radiography course?

I found the course interesting, well-structured and easy to fit around working full time. Logging in was straight forward and it was great to have the option of repeating past content. I really enjoyed it! 
How did you feel about taking the final examination online, rather than going to an exam centre?

Taking the exam online was actually less daunting than going to an exam centre. Plus, as all of the modules had been online, the similarity put me at ease.

\section{Since passing the exam, how} have you used your Radiography qualification?

I have mainly used my qualification for taking OPGs for orthodontic records. I also take PAs when working with our Implantologist and Endodontist.
How did you feel about taking the final examination online?

The course allowed students to download the exam software prior to taking the formal exam. This meant that I was able to familiarise myself with the software in advance, making an online examination feel less daunting.

Since passing the exam, how have you used your OHE qualification? I am currently working with my practice manager to put in place a referral system and the possibility of arranging regular OHE sessions. I am also planning to create topical displays for my practice to help engage and

\section{'CARLY WON THE AWARD FOR ACHIEVING}

\section{THE HIGHEST MARK IN THE EXAM HELD IN}

\section{SEPTEMBER 2014. SHE IS THE FIRST STUDENT}

\section{TO BE PRESENTED WITH THE AWARD FOR OHE.'}

Will you undertake any more further education courses?

Yes, I am going to Cardiff University in September 2015 where my qualification will help me achieve my goal of becoming a Dental Therapist.

\section{Carly Wichall, BDA Education Outstanding OHE Student of 2014}

Carly won the award for achieving the highest mark in the exam held in September 2014. She is the first student to be presented with the award for OHE. Carly qualified as a Dental Nurse in 2011, and has been working at Euro Dental in Swindon for the past five years.

How did it feel to win your prize? The Award ceremony provided an opportunity not only to receive recognition for a lot of hard work, but also to meet and speak with many dedicated and inspirational members of the dental industry. It was an honour to be presented with my award.

What did you think of the online Oral Health Education course?

Working full time whilst studying can be really tough, but via the BDA's online OHE course, I was able to complete modules at a time that suited me. I found the course to be well set out and the accompanying textbook "Basic Guide to Oral Health Education and Promotion" offered excellent support alongside the online lectures. inform patients on the wide range of topics within oral health care.

\section{Will you undertake any more further education courses? \\ I am hoping to continue my education in the dental industry and therefore further my career. I am looking to study to become a dental hygienist.}

The British Dental Association has run online courses for DCPS in Radiography and Oral Health Education since 2006, and began launching its own examinations in these subjects in 2013. Over 1,500 DCPs now hold nationally-recognised BDA qualifications.

If you're interested in expanding your education in a convenient and accessible way, earning verifiable CPD and enhancing your career prospects, then don't hesitate to contact BDA Education with any questions you might have. Please visit https://www. bda.org/dcps or call 02075636888 (Radiography) or 02075634551 (OHE).

bdjteam201590

\section{FLASH INTERVIEW}

\section{Afton McKechnie \\ Afton is a \\ 25-year-old \\ dental nurse \\ at Ivory \\ Dental Care \\ in Blackpool. \\ She lives with \\ her partner \\ Nathaniel \\ and her dog Jessie \\ Name: Afton McKechnie \\ Age: 25 \\ Job title: Dental Nurse. \\ Town: Blackpool. \\ Workplace: Ivory Dental Care. \\ Marital status: Co-habiting.}

Partner's name and job: Nathaniel Litigation Manager.

\section{Children and names: N/A}

How long have you worked in dentistry? Five years.

Why did you choose dentistry for your career? Dentistry has always interested me since I was a young girl. I always used to ask my dentist questions.

Do you have any special responsibilities within your dental practice/workplace? I am responsible for training new Dental Nurse Cadets and Ivory Dental Care social media.

What do you like best about your job? The team I work with.

What is the most challenging part of your job? Time-keeping.

What do you like to do outside work? Socialise with friends, spend time with family and go on holidays.

Tell us a secret. I used to have a crush on a young Jean Claude Van Damme.

What do you like about BDJ Team? It's very friendly and informative.

What three things could you not live without (besides people)? My dog, my toothbrush and bananas!

bdjteam201591 